\title{
スーパオキサイドディスムターゼ(SOD) 修飾電極
}

\author{
西山勝彦・三浦さき子・谷口 功 \\ 熊本大学工学部物質生命化学科 㒸 860-8555 熊本県熊本市黒髪 2-39-1 \\ (2003 年 12 月 27 日受理)
}

\section{Superoxide Dismutase (SOD) Modified Electrodes}

\author{
Katsuhiko NishIYAMA, Sakiko MiURA and Isao TANIGUCHI \\ Department of Applied Chemistry and Biochemistry, Kumamoto University \\ 2-39-1 Kurokami, Kumamoto 860-8555 \\ (Received December 27, 2003)
}

\begin{abstract}
Electrochemical properties and electron transfer processes of biopolymers such as metal proteins or enzymes have been studied extensively, since it provides us important information to understand the redox system in biosystems. However, for example, it is not easy to obtain the reversible electrochemical response of superoxide dismutase (SOD) which dispropornations superoxide to molecular oxygen and hydrogen peroxide catalytically. Recently, electrochemical properties of various types of SODs have been reported using the so called self-assembled monolayer-modified electrodes or other type of functional electrodes. However, the results reported are not necessarily in good agreements. The authors introduce the modified electrode system for CuZnSOD reported by other research groups and describe the redox response of various SODs including CuZnSOD studied by our research group in this article.
\end{abstract}

\section{1. は じめに}

生体では紫外線, 放射線, 大気污染などの外的要因や, 低酸素状態などの内的要因によるストレスに曝されると 生体に傷害を引き起こす作用と免疫作用の 2 つの作用を 有する活性酸素が生成する。活性酸素による生体成分の 損傷は, 脂質に対しては過酸化, タンパク質・酵素に対 しては酸化やニトロ化による不活性化, 核酸に対しては 塩基の酸化および切断である。これらが蓄積するとゲノ 厶異常や発ガンや老化など種々の疾患が生じる。生成し た活性酸素の一部はスーパオキサイドディスムターゼ （SOD）により酸素と過酸化水素に分解される（Fig. 1)。 SOD のような生体高分子の電気化学特性および電子 移動過程を明らかにすることは, 生体システム内外の生 物活性種の酸化還元挙動を解明するための重要な情報で あるため, 金属たんぱく質の酸化還元挙動の生物化学的,

E-mail: nisiyama@gpo.kumamoto-u.ac.jp
生化学的研究が近年盛んに行われている。しかしながら, SOD は, 通常の金, 銀, プラチナ, グラッシーカーボ ン, グラファイト電極を用いたサイクリックボルタンメ トリーでは, 可逆的な電気化学応答は得られない。これ は, 電極表面に SOD 分子が吸着することにより, SOD の変性あるいは活性サイトの立体配位が変化するためと 考えられている。

近年, 金と硫黄の強い相互作用を利用したいわゆる自 己組織化型プロモーター修飾電極 ${ }^{1}$,, あるいは他のタイ プの修飾電極によって $\mathrm{Cu}_{2} \mathrm{Zn}_{2} \mathrm{SOD}$ を始めとする種々の 起源の SOD の電気化学的特性が報告されているが, 測 定結果は必ずしも一致していない。本報では $\mathrm{Cu}_{2} \mathrm{Zn}_{2} \mathrm{SOD}$ の速い電子移動を可能とするこれまで報告されてきた 種々の SOD 用修飾電極について述べるとともに本研究 グループで行った $\mathrm{Cu}_{2} \mathrm{Zn}_{2}$ を含む種々の SOD の酸化還元 応答について述べる。今回用いたあるいは論文で使用さ れた修飾剂分子の構造をその略号と供に Fig. 2 に示し た。また,ここで用いた電位は特に記述しない限り $\mathrm{Ag} /$ 


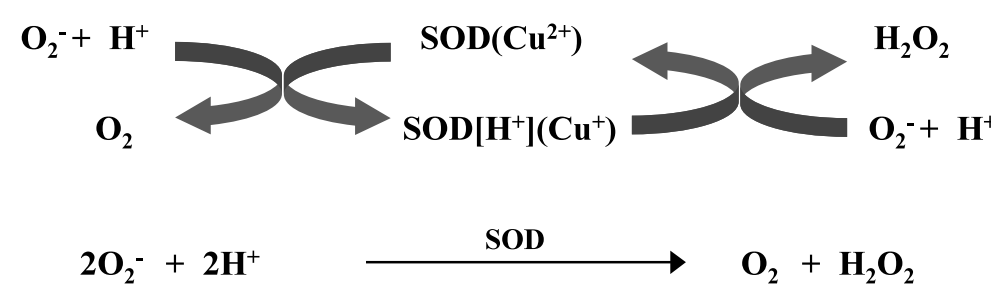

Fig. 1. Schematic illustration of the biological process of superoxide ion dismutation catalyzed by SOD.<smiles>NC(CS)C(=O)O</smiles>

\section{Cystein: Cys}

$\mathrm{HS}\left(\mathrm{CH}_{3}\right)_{2} \mathrm{COOH}$

\section{Mercaptopropionicacid: MPA}

$\mathrm{HS}\left(\mathrm{CH}_{3}\right)_{2} \mathrm{NH}_{2}$

\section{Mercaptoethylemine: MPE}<smiles>Nc1ccnc(S)n1</smiles>

\section{4-Amino-2-mercaptopyrimidine: AMP}

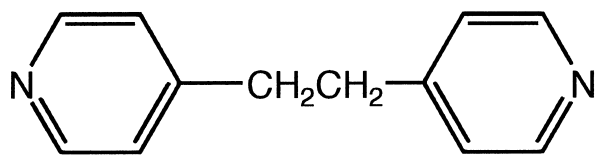

\section{1,2-bis(4-pyridyl)ethane: PyE}

Fig. 2. Chemical structure of modifies and their abbreviations.

$\mathrm{AgCl}$ ( $\mathrm{KCl}$ sat.）基準となっている。

\section{2. 種々の機能電極上でのSODの電気化学応答}

2.1 システィン修飾金ディスク電極での $\mathrm{Cu}_{2} \mathrm{Zn}_{2} \mathrm{SOD}$ の電子移動反応 2

リン酸バッファー中，未修飾金電極上では $\mathrm{Cu}_{2} \mathrm{Zn}_{2} \mathrm{SOD}$
の電気化学的応答は得られなかった。一方, システイン 修飾電極上では, $\mathrm{Cu}_{2} \mathrm{Zn}_{2} \mathrm{SOD}$ と金電極間の電子移動は 促進され, 掃引速度 $100 \mathrm{mVs}^{-1}$ において酸化還元ピー ク電位差 $(\Delta E)$ が $150 \mathrm{mV}$ である準可逆的なボルタモ グラムが得られた。酸化還元電位 $\left(E^{0^{\prime}}\right)$ は, $65 \pm 3 \mathrm{mV}$ であり, ピーク電流は基本的には濃度に比例し, $0.56 \mathrm{mM}$ までは直線的に増加した。また, 掃引回数の増加に伴い, ピーク電流值は時間と供に増加した。すなわち, この条 件下では $\mathrm{Cu}_{2} \mathrm{Zn}_{2} \mathrm{SOD}$ が徐々にシステイン修飾電極上に 固定化されたことを示している。 $\mathrm{Cu}_{2} \mathrm{Zn}_{2} \mathrm{SOD}$ を含まな いリン酸緩衝溶液中でもボルタモグラムは少なくとも 20 分間は安定で, ピーク電流は掃引速度に比例して増 加したことより $\mathrm{Cu}_{2} \mathrm{Zn}_{2} \mathrm{SOD}$ は電極上に比較的安定に固 定されていることが示された。

2.2 システイン修飾金ワイヤー電極上での $\mathrm{Cu}_{2} \mathrm{Zn}_{2}$ SOD 電子移動反応 ${ }^{3)}$

$0.2 \mathrm{mM}$ の硫酸中で前処理した金線電極を $2 \mathrm{mM}$ のシ ステインを含む $\mathrm{pH} 7.0$ のリン酸バッファー溶液に浸漬 し，蒸留水でリンスし風乾することによりシステイン修 飾金ワイヤー電極を作製した。pH 7.0 のリン酸バッファ 一中でのサイクリックボルタモグラムには $\mathrm{Cu}_{2} \mathrm{Zn}_{2} \mathrm{SOD}$ の酸化還元に対応するピーク電流が観測された。酸化ピ ーク電位は $170 \mathrm{mV}$ ，還元電位が $50 \mathrm{mV}$ であり， $E^{\mathrm{O}^{\prime}}$ $110 \mathrm{mV}$ となった。 $\Delta E$ は掃引速度 $10 \mathrm{mV} / \mathrm{s}$ の場合 120 $\mathrm{mV}$ であった。システイン分子は金電極の表面に吸着し ており, $\mathrm{Cu}_{2} \mathrm{Zn}_{2} \mathrm{SOD}$ の測定に用いたシステイン修飾金 ワイヤー電極を超音波洗浄した後でも, $\mathrm{Cu}_{2} \mathrm{Zn}_{2} \mathrm{SOD}$ 溶 液中において同様な電気化学応答が得られた。掃引速度 を変化させたところピーク電流はスキャンレートに比例 したことから $\mathrm{Cu}_{2} \mathrm{Zn}_{2} \mathrm{SOD}$ は電極上に吸着していること が示された。

2.3 MPA 修飾金ワイヤー電極での $\mathrm{Cu}_{2} \mathrm{Zn}_{2} \mathrm{SOD}$ の電 子移動反応 ${ }^{4)}$

$2.5 \mathrm{M} \mathrm{KOH}$ 中で 4 時間煮沸した後, 濃硫酸に一晚浸 漬した直径 $0.5 \mathrm{~mm}$ 金ワイヤー電極を室温で $10 \mathrm{mM}$ MPA 水溶液に 15 分間浸漬し, 純水でリンスすることに より MPA 修飾金ワイヤー電極を作成した。 $\mathrm{Cu}_{2} \mathrm{Zn} 2 \mathrm{SOD}$ 
固定化電極は, MPA 修飾金ワイヤー電極を $200 \mu \mathrm{M} \mathrm{Cu}_{2}$ $\mathrm{Zn}_{2} \mathrm{SOD}$ 溶液（pH 7.5 の $10 \mathrm{mM}$ HEPES バッファー）に $4{ }^{\circ} \mathrm{C}$ で 30 分間浸すことにより作成した。また, 共有結 合による $\mathrm{Cu}_{2} \mathrm{Zn}_{2} \mathrm{SOD}$ の固定化には前述の静電的な吸着 の際に 1-エチル-3(3-ジメチルアミノプロピル) カルボ ジイミドを用いた。

MPA 修飾金ワイヤー電極を用いた場合, $250 \mu \mathrm{M} \mathrm{Cu}_{2}$ $\mathrm{Zn}_{2} \mathrm{SOD}$ (支持電解質は 0.1 M HEPES バッファー $(\mathrm{pH}$ 7.5)）のCVには酸化還元電位が $60 \pm 6 \mathrm{mV}$, ピークセ パレーションが約 $56 \mathrm{mV}$ の酸化還元波が観測された。 ピーク電流は 10〜 $100 \mathrm{mV} / \mathrm{s}$ の掃引速度の範囲では掃引 速度の平方根の值に比例したことから, この条件下では SOD の電極反応は拡散律速であることを示している。 一方, SOD を含まない低いイオン強度バッファー中で は MPA 修飾電極に吸着した $\mathrm{Cu}_{2} \mathrm{Zn}_{2} \mathrm{SOD}$ の明瞭で安定 な応答を得られた。サイクリックボルタモグラムより求 めた $E^{\mathrm{O}^{\prime}}$ は $\mathrm{Cu}_{2} \mathrm{Zn}_{2} \mathrm{SOD}$ が吸着している状態では $47 \pm 6$ $\mathrm{mV}, \Delta E$ は $39 \pm 9 \mathrm{mV}$ であった。一方, 共有結合によ りSOD を電極用面に固定化した状態では $E^{\mathrm{O}}$ が $56 \pm 9$ $\mathrm{mV}$ （pH 7.5） $\Delta E$ は $54 \pm 10 \mathrm{mV}$ であった。酸化還元ピ 一ク電流は 10〜 600 mV 間で掃引速度に比例しており夕 ンパクが電極表面に固定されていることが示された。

MPA は短いアルキル鎖を持っており金電極上で単分 子膜を形成している。未端のカルボシキル基は $\mathrm{pH} 7.5$ では解離していると考えられ，電極表面は負電荷を帯び ることになる。この $\mathrm{pH}$ で $\mathrm{Cu}_{2} \mathrm{Zn}_{2} \mathrm{SOD}$ は全体としては 負電荷を帯びているが，部分的に正電荷を帯びた活性中 心との静電的な相互作用吸着していると考えられる。モ ル分率 9:1 で MPA とメルカプトエチルアミン（MEA） を混合し, 電極表面が弱くネガティブチャージするよう にしても $\mathrm{Cu}_{2} \mathrm{Zn}_{2} \mathrm{SOD}$ の吸着量, 酸化還元反応の可逆性 等に変化は見られない。しかし興味深いことに, 吸着の $\mathrm{Cu}_{2} \mathrm{Zn}_{2} \mathrm{SOD}$ の $E^{\mathrm{O}}$ は MEA のモル分率が増加するごとに わずかに高くなる。

\section{4 金マイクロ電極を用いた $\mathrm{Cu}_{2} \mathrm{Zn}_{2} \mathrm{SOD}$ の電気化 学応答5)}

未修飾の直径 $50 \mathrm{~mm}$ の金マイクロディスクを用いて $\mathrm{Cu}_{2} \mathrm{Zn}_{2} \mathrm{SOD}$ 溶液中の酸化還元波が観測された。E $E^{\mathrm{O}}$ は約 $220 \mathrm{mV}, \Delta E$ は約 $100 \mathrm{mV}$ であった。Cu2Zn $\mathrm{Cu}_{2} \mathrm{SOD}$ の濃度 は通常のタンパク質電気化学の測定条件よりも比較的高 い $260 \mu \mathrm{M}$, 支持電解質には $\mathrm{pH} 7.0$ のリン酸バッファー を用いた。ピーク電流は掃引速度にほぼ比例しており $\mathrm{Cu}_{2} \mathrm{Zn}_{2} \mathrm{SOD}$ は電極に吸着していると考えられる。

\section{$2.5 \mathrm{PyE}$ 修飾金電極での $\mathrm{Cu}_{2} \mathrm{Zn}_{2} \mathrm{SOD}$ の電気化学的} 応答6)

pH 7.4 のリン酸バッファー中プロモーターとして 0.1
mM 1,2-bis (4-pyridyl) ethane (PyE) を用いた場合の $\mathrm{Cu}_{2} \mathrm{Zn}_{2}$ SOD の酸化還元電位は $120 \pm 10 \mathrm{mV}$ であった。PyEには チオール基が存在しないため, 吸着力はそれほど高くな いが，ピリジン部位と金との相互作用で電極に吸着して いるものと考えられる。PyEの配向に関しての情報はな いため，2つのピリジル基の両方が金と相互作用してい る並行的な配向，あるいは 1 つのピリジル基のみが吸着 している垂直的な配向であるかは不明である。 pH 7.4 で はピリジル基はプロトン化しているとは考えにくく, 静 電的な相互作用というよりもむしろ $\mathrm{Cu}_{2} \mathrm{Zn}_{2} \mathrm{SOD}$ が金に 変性して吸着することを防いでいると考えられる。酸化 還元電位は $\mathrm{pH}$ 5〜 pH 9 の範囲で $\mathrm{pH}$ が増加するごとに $55 \mathrm{mV} / \mathrm{pH}$ で減少した。この条件では酸化還元反応に関 与する電子とプロトンの比はほぼ 1 であると考えられ る。

2.6 メディエーターを用いた $\mathrm{Cu}_{2} \mathrm{Zn}_{2} \mathrm{SOD}$ の分光電 気化学7)

作用電極として金グリッド電極, 十分な吸光度の変化 を得るために $2 \mathrm{~cm}$ の光学セルを用いた長光路分光電気 化学測定を行った。メディエーターとしては $\mathrm{Cu}_{2} \mathrm{Zn}_{2} \mathrm{SOD}$ の 6 倍の濃度の $\left[\mathrm{K}_{3} \mathrm{Fe}(\mathrm{CN})_{6}\right]$ を用いた。

SOD の酸化体はメディエーターによって還元され, 酸化体と還元体の比は波長 $680 \mathrm{~nm}$ をモニタすることに より決定した。 $\mathrm{Cu}_{2} \mathrm{Zn}_{2} \mathrm{SOD}$ の酸化と還元の濃度比は各 印加電位における吸光度から決定し, 酸化還元電位は $209 \mathrm{mV}$ となった。

\section{3. 種々の起源の SOD の酸化還元電位と酸化 還元電位の修飾電極による依存性 ${ }^{81}$}

これまで報告してきた実験方法とその方法により測定 された酸化還元電位を Table 1 にまとめた。酸化還元電 位は $220 \mathrm{mV} \sim 47 \mathrm{mV}$ の範囲に分布している。基本的に は SOD は吸着種として反応しており, 若干の構造変化 あるいは活性中心の微妙な環境の変化が酸化還元電位に 影響を与えていると著者は考えている。SOD としての 機能を評価することで未変性であることを証明すること はこの系においては容易なことではない。本研究グルー プでは SOD のi）起源および ii）活性中心の違いに着目 し，主に電極表面の電荷に着目した 3 種類の修飾剤を用 いて種々のSODの酸化還元反応を追跡した。Bovine erythrocyte 由来の $\mathrm{Cu}_{2} \mathrm{Zn}_{2} \mathrm{SOD}$ の全体的な構造と分子量, 残基数などのデータを Fig. 3 に示した。用いた修飾剤は これまで用いられてきた Cys（両性イオン型）, MPA（ア ニオン型) に加えてピリミジン環を骨格としてアミノ基 を有するチオールである AMP である（Fig. 2)。

Bovine erythrocyte 由来の $\mathrm{Cu}_{2} \mathrm{Zn}_{2} \mathrm{SOD}$ の CV を Fig. 4 
Table 1. Redox potential of CuZnSOD obtained by electrode systems.

\begin{tabular}{llc}
\hline \multicolumn{1}{c}{ Electrode } & Method & Redox potential vs Ag/AgCl \\
\hline Cys/Au-Disk & $\mathrm{CV}$ & $65 \pm 3 \mathrm{mV}$ \\
Cys/Au-Wire & $\mathrm{CV}$ & $110 \mathrm{mV}$ \\
MPA/Au-Wire & $\mathrm{CV}$ & $47 \pm 6 \mathrm{mV}$ \\
$\mathrm{Au}-\mathrm{Microdisk}$ & $\mathrm{CV}$ & $220 \mathrm{mV}$ \\
$\mathrm{Au}+\mathrm{PyE}$ & $\mathrm{CV}$ & $120 \mathrm{mV}$ \\
$\mathrm{Au}+\mathrm{Fe}[(\mathrm{CN}) 6]^{3-}$ & Spectroelectrochemistry & $209 \mathrm{mV}$ \\
\hline
\end{tabular}

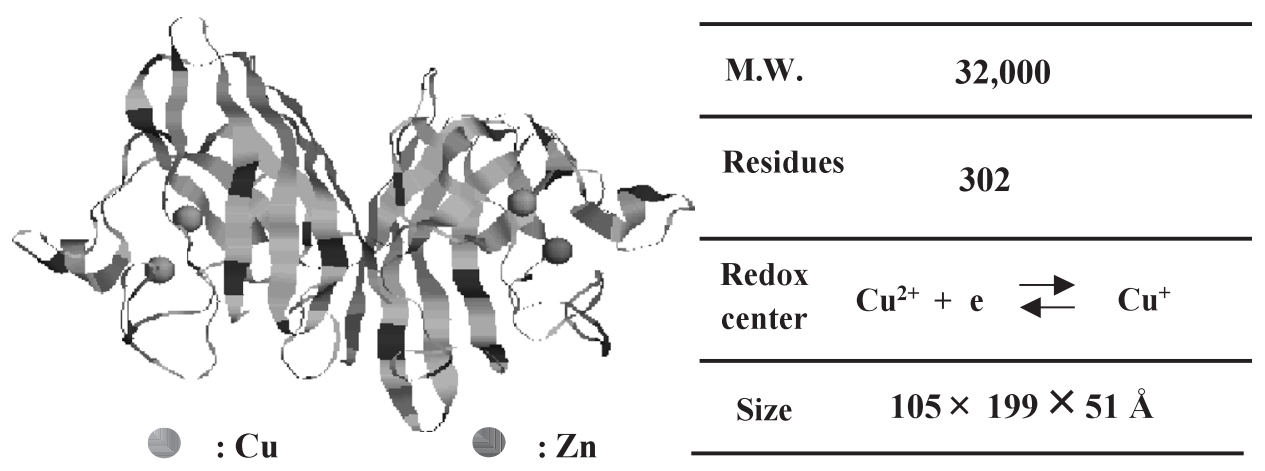

Fig. 3. Structure and properties of $\mathrm{Cu}, \mathrm{Zn}-\mathrm{SOD}$ from Bovine erythrocyte.

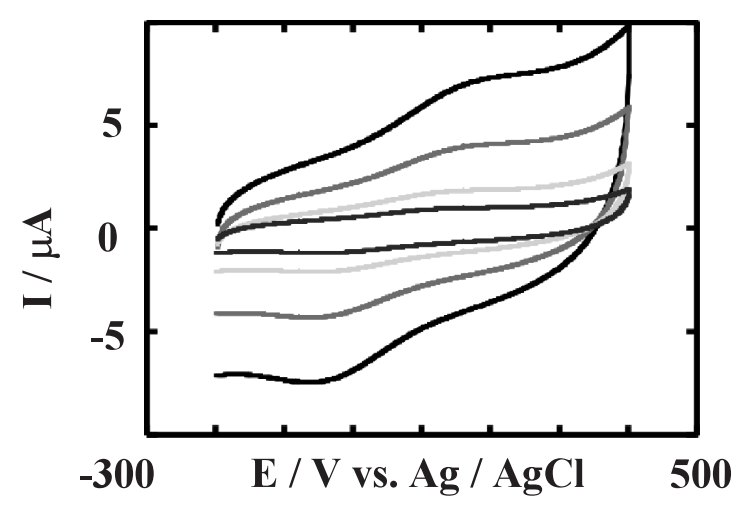

(a)

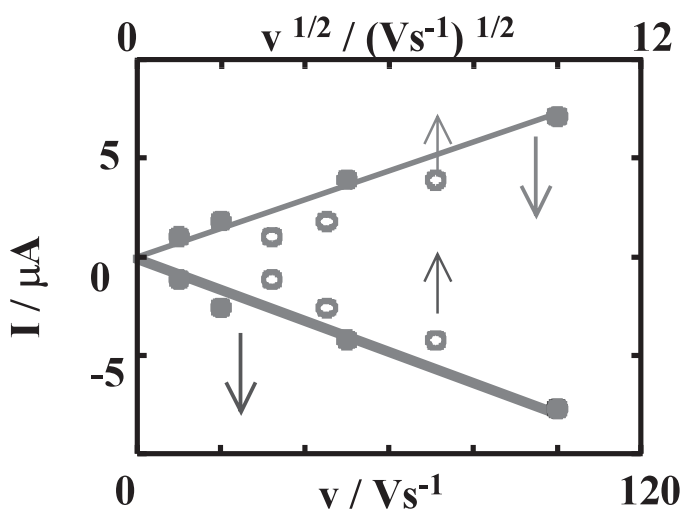

(b)

Fig. 4. (a) CVs of SOD from Bovine erythrocyte in $27 \mathrm{mM}$ Bis-Tris buffer solution (pH 7.8) containing SOD at cystein modified Au wire electrode. Scan rate: 10, 20, 50, $100 \mathrm{mVs}^{-1}$. (b) Plots of $I \mathrm{p}_{\mathrm{a}}$ and $I \mathrm{p}_{\mathrm{c}} \mathrm{vs}$. v or $\mathrm{v}^{1 / 2}$. Date were taken from Fig. 4 (a).

に示した。明膫な酸化還元波が観測され, 酸化還元電位 は $67 \mathrm{mV}$ とほぼこれまで報告された值と一致した。酸 化還元電流は掃引速度に比例していることから電極表面 に吸着していることがわかった。

酸化還元中心として $\mathrm{Cu}, \mathrm{Zn}$ を有する SOD に加えて 起源の異なる Fe-SOD, Mn-SOD など 6 種の SOD の測 定を行った（Table 2)。SOD は中性領域で負に帯電して いることから，アミノ基を有する AMP をプロモーター として用いたが，ほとんどの場合この電極上では応答が 得られなかった。ただし, Cys, AMPで全く応答が得ら れなかった E. coli 由来の Mn-SOD に関して若干ながら
応答が見られたことは SOD の起源あるいは活性中心の 構造によっては AMP が有効なプロモーターとして機能 する可能性が残っている。

Cys 修飾電極上では E. coli 由来の Mn-SOD の場合を 除いた 5 種類の SOD の電極反応が観測された。また, MPA 修飾電極上では 3 種類の SOD の酸化還元応答が観 測された。興味深いことに，MPA 上で得られた酸化還 元電位は Cys 上で得られた酸化還元電位とは異なる值 となった。Bovine erythrocyte の場合は MPA 上の值が 70 $\mathrm{mV}$ 高く, Human の場合は $17 \mathrm{mV}$ 高くなったが， E. coli （Fe-SOD）の場合は $73 \mathrm{mV}$ 低い值となり，これらの全 
Table 2. Redox potential of several kinds of SODs obtained from cyclic voltammetry at modified electrodes.

\begin{tabular}{ccccccc}
\hline Modifier & $\begin{array}{l}\text { Bovine erythrocyte } \\
\text { Cu, Zn-SOD }\end{array}$ & $\begin{array}{l}\text { Human } \\
\text { Cu, Zn-SOD }\end{array}$ & $\begin{array}{l}\text { E. coli } \\
\text { Fe-SOD }\end{array}$ & $\begin{array}{l}\text { E. coli } \\
\text { Mn-SOD }\end{array}$ & $\begin{array}{c}\text { P. gingivlis } \\
\text { Fe-SOD }\end{array}$ & $\begin{array}{c}\text { P. gingivlis } \\
\text { Mn-SOD }\end{array}$ \\
\hline Cys & $67 \mathrm{mV}$ & $85 \mathrm{mV}$ & $-40 \mathrm{mV}$ & $\times$ & $73 \mathrm{mV}$ & $74 \mathrm{mV}$ \\
MPA & $127 \mathrm{mV}$ & $102 \mathrm{mV}$ & $-113 \mathrm{mV}$ & $\times$ & $\triangle$ & $\times$ \\
AMP & $\times$ & $\times$ & $\times$ & $\triangle$ & $\times$ & $\times$ \\
\hline
\end{tabular}

ての結果を合理的に説明することは容易なことではな い。基本的には今回用いた SOD は吸着種として反応し ているため電極表面の電荷状態が吸着状態あるいは SOD の構造に比較的大きく影響を与えていると考えら れる。

\section{4.おわりに}

酵素固定化電極としてスーパオキサイドディスムター ゼ（SOD）のための修飾電極あるいは機能電極の紹介お よび著者の研究グループで行った結果を紹介した。酸化 還元電位は活性部位, 由来に応じて異なることが示され たが, 逆に 1 種類の SOD を異なる修飾電極で測定した 場合は必ずしも得られる酸化還元電位は一致しないこと が示唆された。SODを用いた活性酸素センサーの研究 も増えているようであるが, 可能な限り機能を維持した 状態で固定化する方法の開発が必要であろう。

\section{文献}

1) I. Taniguchi: Interface 4, 34 (1997) and references therein.

2) Y. Tian, M. Shioda, S. Kasahara, T. Okajima, L. Mao, T. Hisahori and T.Ohsaka: Biochim. Biophys. Acta 1569, 151 (2002).

3) X. Meng, X. Wu, Z. Wang, X. Cao and Z. Zhang: Bioelectrochemistry 54, 125 (2001).

4) B. Ge, F.W. Scheller and F. Lisdat: Biosensors and Bioelectronics 18, 295 (2003).

5) X. Wu, X. Meng, Z. Wang and Z. Zhang: Bioelectrochemistry and Bioenergetics 48, 227 (1999).

6) H.A. Azab, L. Banci, M. Borsari, C. Luchinat, M. Sola and M.S. Viezzoli: Inorg. Chem. 31, 4649 (1992).

7) C. Clair, B. Gay and J. Valentine: Inorg. Chem 31, 925 (1992).

8) K. Nishiyama, S. Miura and I. Taniguchi: manuscript to be submitted. 